\title{
ENVIRONMENT
}

\section{Russia and the North}

Edited by E. Wilson Rowe. 2009. University of Ottawa Press, 542 King Edward Avenue, Ottawa, Ontario K1N 6N5 Canada. 218 pages, 22 USD.

This book makes for an interesting document in time. It's a traditional-style western information source on Russia and its Arctic policy, but also on Norwegian perspectives. It is written by nine authors (six from Norway, only two from the US, and just one from Russia). The editor is E. Wilson Rowe from the Fridtjof Nansen Institute in Oslo, Norway. The central schemes of this book are wrapped around the economic developments in the Barents Sea and the Kara Sea, and thus Russia's claim to the North Pole, prominent oil and gas topics, fisheries issues, interfering indigenous perspectives, and climate change are dealt with. Most readers will appreciate learning about Russian's history of decision making and its fluctuating long-term strategy, as well as facts and underlying reasons for building "Fortress Russia" and its peculiar and globally inconsiderate behaviour of "muscle building".

The editor starts with a nice introduction to Russia's aims and realities ("The North accounts for twenty percent of Russia's gross domestic product", ".... and paid forty-seven percent of all taxes collected by the Russian state in 2006."). However, no statement is made that Russia's shock therapy to capitalism widely failed and resulted, for instance, in shorter life expectancies. P. Baev from the Peace Research Institute of Oslo (PRIO) presents the first chapter on Russian military strategy and related activities: Russian development clearly means militarization!

The second chapter, by G. Hønneland (Fridtjof Nansen Institute, University of Tromsoe), deals with cross-border cooperation in the Barents Euro-Arctic Region (BEAR), involving Norbotten (Sweden), Lapland (Finland), Murmansk Oblast, Arkhangelsk Oblast (region), and the Republic of Karelia. Namely, work of the Barents Euro-Arctic Council (BEAC; Canada, France, Germany, Italy, Japan, the Netherlands, Poland, UK, and US all have strategic observer status) gets described. The fact that Russia ignored many environmental issues (for instance, for the infamous Pechenganikel combine; Norilsk Nickel smelter) is documented, as is the fact that conflicts between the Federal Service for Surveillance in Ecology and Resource Use (Rosprirodnadzor) and the Federal Service for Ecological, Technical and Nuclear Surveillance (Rostekhnadzor) resulted in (purposeful?) confusion and inefficiency for no relevant change. Once joint ventures became profitable, Russia reaped many economic advantages for itself at will in BEAR. But on the good side, personal relationships on all sides of the borders benefited greatly within BEAR and its initiatives, e.g., the indigenous Lapp people.

The third chapter, by C. ZumBrunnen (University of Washington, Seattle), is among my favourites. It deals primarily with climate change in the Arctic and its implications for Russia. This highly informative section describes relevant Russian statistics and indicators showing climate change in the Russian Arctic beyond any reasonable doubt, causing many pipeline breaks and affecting industrial population centres and the Trans-Siberian and Baikal-Amur railways. These facts matter, because for a long time the head of the Russian Academies of Science Institute of Climatology and Ecology (Yu. Izrael) and the head of the Institute of the Earth's Cryosphere (V. Melnikov) stated, in a self-serving manner for Russia's oil industry, that climate change would actually be good for the country and more $\mathrm{CO}_{2}$ should therefore be put into the atmosphere! Together with the infamous citations by A. Illarionov (economic adviser to V. Putin) comparing the Kyoto Protocol to fascism and stating that the "...theory of global warming is not borne out by scientific data and is, strictly speaking, charlatanism", this documents Russia's traditionally egoistic and poor leadership all over again. Further, Russia's problem with flaring gas gets described (an environmental/economic waste and an oddity when wanting to reduce carbon emissions). This is nicely balanced by ZumBrunnen, who outlines Exxon Mobil's 16 million USD campaign to distort the facts of climate change and the fact that the Bush administration interfered with climate science, imposed censorship on its scientists, and blocked the ratification of the Kyoto Protocol in the United States. (Russia did ratify it, and the EU supported Russia's application to join the World Trade Organization right afterwards!) The author states that Russian $\mathrm{CO}_{2}$ output is directly related to its economic performance (it basically means that Russia accumulates wealth at the cost of the global community).

Another informative chapter is written by A.-K. Jørgensen (Fridtjof Nansen Institute), who is also a fisheries observer in Russia. Jørgensen elaborates on the subject of (Arctic) fisheries. The Arctic cod stocks are among the largest in the entire Atlantic, and the bulk of the contractually shared Norwegian-Russian resource swims on the Russian side. The author describes intense Russian overfishing of many Barents Sea stocks, Russia's resistance to recommendations by the International Council for the Exploration of the Sea (ICES), and the inherent crime and corruption of Russia's "unreformable" fisheries sector and the Federal Research Institute of Fisheries and Oceanography (VNIRO). Further, the Murmansk trawl fleet, subsidies, quota trading, and governmental attempts to overcome problems by means of restructuring (Law 303), as well as open market approaches to fish auctions that worked nowhere else, are discussed (views from 
D. Pauly et al. are unfortunately ignored, though). Noteworthy is the fact that Russia has a policy to provide each citizen with a guaranteed $26 \mathrm{~kg}$ of fish per year.

Another crucial topic of relevance to world security-Russia's offshore oil and gas resources-is taken on by A. Moe (Fridtjof Nansen Institute) and the editor herself. The Soviet Union has been among the world's largest oil and gas producers in the world. This picture has hardly changed, and the EU-widely without such natural resources-is still among the biggest consumers of Russian gas. The Arctic is perceived as a safe location for oil and gas production (a view everybody should take issue with). GAZPROM (with close political ties to D. Medvedev) is the largest gas producer in Russia, and likely in the world, carrying the export monopoly, whereas ROZNEFT is stronger regarding oil production, but is closely affiliated with V. Putin. Both companies interfere but basically obtained the Russian monopoly through law. Not just Norwegian STATOIL and Russian GAZPROM and ROZNEFT cooperate in the Barents Sea, but companies like French TOTAL are also involved. Global security issues and NATO must be considered here, too. The Russian off- and onshore development of carbon resources includes liquefied natural gas (LNG). Development and leasing strategies for the next 40 years in the Pechora Sea, the Shtokman gas field in the Barents Sea, Ob-Tazov Bay, and the Kara Sea are outlined.

A subsequent chapter by T. Heleniak (University of Maryland) on growth poles (industrial centres) and ghost towns tackles the general notion of "fleeing the Arctic", poverty traps for immigrants (such as Chukotka and Magadan), few new immigration centers (such as Tuva), long-distance shift-work, and the Bishkek Protocol. As found elsewhere, globally failed World Bank policies became clear once more when the World Bank borrowed 80 million USD in 2001 for the Northern Restructuring Project, naively trying to promote economic growth in the Arctic. But Russia overrules economic arithmetic with political means.

It's easy to detect in this book the fact that the 39 indigenous peoples in Russia have no direct voice in this book, e.g., via representatives of RAIPON (Russian Association of Indigenous Peoples of the North). But two chapters are devoted to them. I. Øverland from the Norwegian Institute of International Affairs presents fresh perspectives on (international) indigenous rights: Convention (labour standard) 107 of the International Labour Organization (ILO) and its update, Convention 169 (not signed by Germany, for instance). Article 69 of the Russian constitution "...guarantees the rights of small indigenous peoples in accordance with the generally accepted principles and standards of international law". But without ratification of the new ILO 169 Convention, such words are becoming a farce. Other crucial topics are the legal definition of indigen- ousness, recognition of indigenous groups as peoples (Article 1 of the Charter of the United Nations), and the relevance of urban lifestyles (15\% of the northern indigenous population in Russia is still nomadic). Other aspects of this chapter are centered on subsurface rights (e.g., for oil, gas, and mining), which are mostly owned by the government and international corporations.

Finally, A. A. Sirina presents a voice from the Russian Academy of Sciences, outlining the inherent conflict between oil and gas development and northern indigenous people, such as the Evenki and Yakut. It is shown that $60 \%$ of the federal budget comes from revenues from exporting oil and gas and that ethnoterritorial bodies were used by the regional oil and gas elite to achieve their own political goals. Examples are found in the Eastern Siberia-Pacific Ocean (ESPO) oil pipeline, the world's longest pipeline (it had the infamous routing problem near Lake Baikal).

The afterword by the editor shows the intersection of northern and national policies and why Russia thinks it can afford to be so assertive at most levels (e.g., the Arctic Military Environmental Cooperation program-AMEC - signed by Russia, Norway, and the US). Instead of modern and careful diplomacy and world peace, V. Putin still seems to be trying to restore Russia's great power status and using vertical structures. But there can be no doubt about the geostrategic role of Siberia, e.g., large nickel, gold, lead, coal, and silver resources are located at a crucial international crossroad linking the Arctic, Europe, Asia, and the Pacific Rim. The book leaves no doubt that the new Russia is aggressive and puts no relevant emphasis on environmental issues. Consequently, many environmental impact studies are flawed and public hearings have been manipulated and politically driven to make money at all costs for the benefit of only a few.

All chapters of this book are well written and edited. They are well supported with references and are generally a great pleasure to read. The reader will appreciate the list of contributors, the list of abbreviations, annotated footnotes, and the detailed nine-page index, which turns this publication into a good reference source.

However, this high-profile book lacks any competence on Arctic biodiversity issues, as well as on online data portals, e.g., for the Barents Sea and Circumpolar. It must further be seen as an oversight on the editor's part that relevant island politics of Svalbard and Wrangel are virtually ignored! The same is true for Arctic shipping, Siberian wetland issues, and the otherwise prominent $\mathrm{FSB} / \mathrm{KGB}$ and arms trade topics. But this book makes no mistake in the provision of facts about modern Russia and its politics. However, as the list of authors and funding shows (the oil and gas chapter, for instance, is funded by the Research Council of Norway directly!), the Norwegian texts and institutions are somewhat one-sided, do not go 
about it in a balanced way, and do not promote a truly international Arctic.

Many relevant Russian references are not cited, e.g., F. Shtilmark. Celebrating a western economically motivated view of Russia, as practised for centuries, is not necessarily a good objective or a healthy one. For instance, the folly of continuing to invest in the carbon industry in the year 2009 is not mentioned, and the role of China as a main player for Russia, for the Arctic and globally, is virtually not represented. The same can be said for tropical nations that are tightly linked to the poles through climate and resource questions. It gets rather annoying when the book does not mention Norway's bad role in global carbon pollution and climate change or that Norway has already overharvested some of its own fish stocks (as publicly recognized by the Conservation of Arctic Flora and Fauna, CAFF). Norway's treatment of indigenous people is not always appreciated by all stakeholders either.

The authors easily condemn the Russian (radioactive) pollution in the Kola region and the Barents Sea, but they are surprisingly quiet on the subject of whether traded Norwegian fish stocks are contaminated (a fact that is well documented in Polar Bears, for instance, which are an inherent part of the same Arctic food chain). Also, this book leaves out the peculiar fact that Norway does not support the EU but its approximately 4 million citizens benefit greatly from many aspects of the nearby EU market and EU funding schemes. Not surprisingly, I find that the dramatic problem of a ruthlessly applied economic growth policy in the Arctic gets entirely ignored by the authors (it is suggested that the audience read Czech (2008), for instance).

I conclude that this book is helpful in understanding modern Russia, as well as the one-sided Norwegian Arctic, oil and gas and fisheries views, and the North overall. But together with books like Chaudhary et al. (2007), it just makes for one more Norwegianbiased publication that promotes strategic and onesided western resource extraction views to a global audience which is not given all the facts to differentiate correctly, see all impacts, and understand the complete picture. Such attempts will not be helpful for building trust if all global citizens ought to live together peacefully and for sharing the global wealth for mutual benefit beyond the time when Norwegian oil and gas, fish, and related money run out, and when adjacent Russian resources and global influence as a military superpower will become even more dominant.

\section{Literature Cited}

Chaudhary, R. P., T. H. Aase, O. R. Vetaas, and B. P. Subedi. 2007. Local Effects of Global Change in the Himalayas. Tribhuvan University, Manang, Nepal, and Uniforskning Bergen, Norway. 199 pages.

Czech, B. 2008. Prospects for reconciling the conflict between economic growth and biodiversity conservation with technological progress. Conservation Biology 22: 1389-1398.

\section{FALK HuETtManN}

EWHALE lab, Biology and Wildlife Department, Institute of Arctic Biology, University of Alaska, Fairbanks, Alaska, USA

\section{MiscELLANEOUS}

\section{Arthur Carhart, Wilderness Prophet}

By Tom Wolf. 2008. University Press of Colorado, 5589 Arapahoe Avenue., Suite 206C, Boulder, Colorado 80303 USA. 294 pages, 42.92 USD.

"The smartest landscape architect is the one who is clever enough to fit the use pattern deftly to the existing conditions with the least physical change needed to adapt site to use." So wrote Arthur Carhart in 1961 near the end of his career as a planner and landscape architect. His career began in 1917 with a Chicago landscape architectural firm, and he went on from there to become the first landscape architect in the US Forest Service (1919-1923). During this time he married and moved to Denver, Colorado, where he made his home for the rest of his life. He followed his formative years in a career as a wilderness writer with at least eight novels as well as many hunting and fishing guides over a period of 45 years. He also wrote numerous articles for magazines. His career embraced landscape, conservation, and recreation issues associated with the American forests. He was an advocate, political activist, planner, and defender of wilderness land-use issues. He also gained popularity as a radio personality for about 15 years in the Denver area.

Carhart (1892-1978) lived in the unique time when the United States wilderness emerged from visits by aboriginal people, trappers, hunters, and pioneers to the time of vacationers travelling by automobile. One of his first projects and one which shaped his perspective throughout his career was a wilderness area assigned to him by the Forest Service at Trappers Lake, Colorado. Trappers Lake was an ancient Ute Native sacred site at the head of a watershed. Early unrestricted development had made its shores unsightly, and the limited water access made sewage pollution a problem as the number of visitors increased. Over a 30-year period, he studied, advocated for and developed detailed plans for the preservation and recreational 